\title{
Utilization of Sugar Beet Industrial filter cake waste for removal of direct red 81 from aqueous solution
}

Aref A.M Aly ${ }^{1}$, Mohamed M.Abd El-Wahab ${ }^{1}{ }^{2}$ Sedky H. A.Hassan $^{3}$, Ibrahim A. EL - Ghany ${ }^{4}$, Abeer A.A.Farrag ${ }^{2}$

Corresponding author Email: aref @ aun.edu.eg

${ }^{1}$ Chemistry Department, Faculty of Science, Assiut University, Assiut71516, Egypt

${ }^{2}$ Faculty of Sugar and Integrated Industries Technology, Assiut University, Assiut, Egypt

${ }^{3}$ Botany \& Microbiology Department, Faculty of Science, New Valley, 72511- El-Kharga- Egypt

${ }^{4}$ Delta Sugar Company, El-Hamoul,Kafr El-Sheikh, Egypt.

\section{Abstract}

A low cost adsorbent has been tested for its adsorption ability to remove a hazardous dye from textile wastewater. The paper assess the results pertaining to the investigation conducted on the removal of the azo sulphonated dye, direct red 81 by adsorption on the filter cake waste as adsorbent. Adsorption studies were carried out in batch mode to examine the influence of various parameters affecting the removal efficiency of the adsorbent. Isotherm data were found to fit well with the Frendlish adsorption mode .From the estimated mean adsorption energy of 3.8 $\mathrm{kJmol}^{-1}$ according to the D-R isotherm model and fitting with the pseudo second-order rate equation, we concluded that the adsorption process of the dye onto filter cake is a physical process with some contribution from chemical adsorption.

Keywords: Adsorption, Direct red 81, Filter cake, Isotherm, Kinetics.

\section{1-Introduction}

Dyes are widely utilized in many industries such as textiles, cosmetics, and plastics. The effluents discharged from these industries are highly colored and pose serious environmental hazards. Various processes were adapted for dye removal including physical, chemical and biological schemes. Adsorption technique is the most preferable due its flexibility, simplicity in design and its 
low cost and removal of colored pollutants from industrial wastewater and therefore it is regarded as an important application of adsorption process ${ }^{[1,2]}$. The remediation of different types of dyes using inorganic materials was the subject of many papers in recent years ${ }^{[3,4]}$.Among the studied dyes are the direct dyes including direct red $81^{[5,6,7]}$.

Filter cake is a by product that results from treatment of nonsugars during extraction of sugar from beet by addition of lime water and carbon dioxide. The produced precipitate is mainly calcium carbonate together with other compounds and minerals. However, the use of filter cake as an adsorbent for dyes is very scare in the literature ${ }^{[8]}$.Therefore we undertook this investigation to throw more light on the potential application of filter cake for the remediation of dyes and we selected direct red 81 for this investigation. The study included the effect of the experimental conditions on the dye removal as well as evaluating the isotherms and kinetics of the adsorption process on the filter cake.

\section{Experiments}

\subsection{Materials}

\subsubsection{Adsorbate}

Direct Red 81, having molecular formula $\mathrm{C}_{29} \mathrm{H}_{19} \mathrm{~N}_{5} \mathrm{Na}_{2} \mathrm{O}_{8} \mathrm{~S}_{2}$ and molecular weight $676 \mathrm{~g} \mathrm{~mol}^{-1}$ was purchased from SigmaAldrich. The structure is shown in Figure.1. Maximum absorption wavelength of the dye is $509 \mathrm{~nm}$. Dye stock solution was 1000 $\mathrm{mg} / \mathrm{L}$. The solutions of concentration $10-80 \mathrm{mg} / \mathrm{L}$ were prepared in distilled water by diluting the stock solution with distilled water.

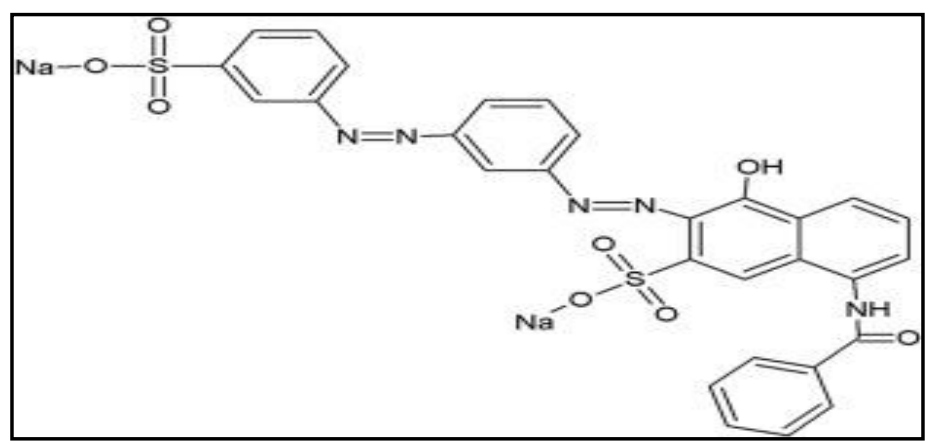

Figure.1 Structure of direct Red 81 


\subsubsection{Adsorbent}

Filter cake was collected from beet Sugar Company located in EL Delta, Egypt. It was washed with distilled water to eliminate dust, impurities and other unwanted chemicals. The samples were dried in an oven at $60{ }^{\circ} \mathrm{C}$ for one day. After this step, all samples were ground and sieved in order to measure the particle size. The powdered sample was then placed and kept in a desiccator for future use. The particle size distribution of filter cake was measured by sieving size range $0.063-0.25 \mathrm{~mm}$.

\subsection{Analytical method}

Dyes concentrations were determined using absorbance values measured before and after the adsorption by a UV-VIS Spectrophotometer (Nicolet Evolution 100) at the wavelength 509 $\mathrm{nm}$. In all cases a proper dilution was necessary to obtain a well measurable absorption.

\subsection{Batch studies}

In all studies $50 \mathrm{ml}$ solution batch was used to investigate the various factors affecting the adsorption of direct red 81 on the filter cake. Only one gram of the adsorbent was used in each experiment. The $\mathrm{pH}$ of the solutions was regulated using $\mathrm{HCl}(0.1 \mathrm{~N})$ or $\mathrm{NaOH}$ $(0.1 \mathrm{~N})$. The adsorption capacity $\left(\mathrm{q}_{\mathrm{t}}\right)$ at time $(\mathrm{t})$ was calculated from the mass balance equation that is given in Eq. (1)

$$
\left.\mathbf{q}_{\mathrm{t}}(\mathbf{m g} / \mathrm{g})=\left[\mathbf{C}_{\mathbf{0}}-\mathbf{C}_{\mathrm{t}}\right) / \mathbf{m}\right] * \mathbf{V}
$$

where $\mathrm{q}_{\mathrm{t}}$ is direct red 81 biosorption capacity in $\mathrm{mg} \mathrm{g}^{-1}, \mathrm{~V}$ is the volume of the direct red 81 dye solutions in liters and $\mathrm{m}$ is the amount of biosorbent (filter cake) in gram, $\mathrm{C}_{\mathrm{o}}$ and $\mathrm{C}_{\mathrm{t}}$ are initial and final equilibrium dye concentrations in $\mathrm{mg} \mathrm{L}^{-1}$, respectively.

The removal efficiency of the dye was also determined using the following equation:

$$
\text { R.E \% }=\left(\mathbf{C}_{\mathbf{0}}-\mathbf{C}_{\mathrm{t}}\right) / \mathbf{C}_{\mathbf{0}} * \mathbf{1 0 0}
$$

where R.E \% is the percentage of dye removed. 


\section{Results and Discussion}

\subsection{Adsorption of direct red 81 onto filter cake.}

Adsorption of direct red 81 from aqueous solutions filter cake adsorbent is affected by several factors including dose, $\mathrm{pH}$, initial concentration of dye, contact time and temperature.

\subsubsection{Effect of adsorbent dosage on the adsorption of the dye.}

The effect of filter cake mass on the dye adsorption was studied by varying the amount of this adsorbent in the range of 0.2 6 g. The samples were shaked over a period of $2 \mathrm{~h}$ at room temperature. The results in Figure. 2 show that the efficiency of removal increases by increasing mass of the adsorbent up to $4 \mathrm{~g}$. This increase was expected and could be due to the presence of more binding sites and surface area on the adsorbent.

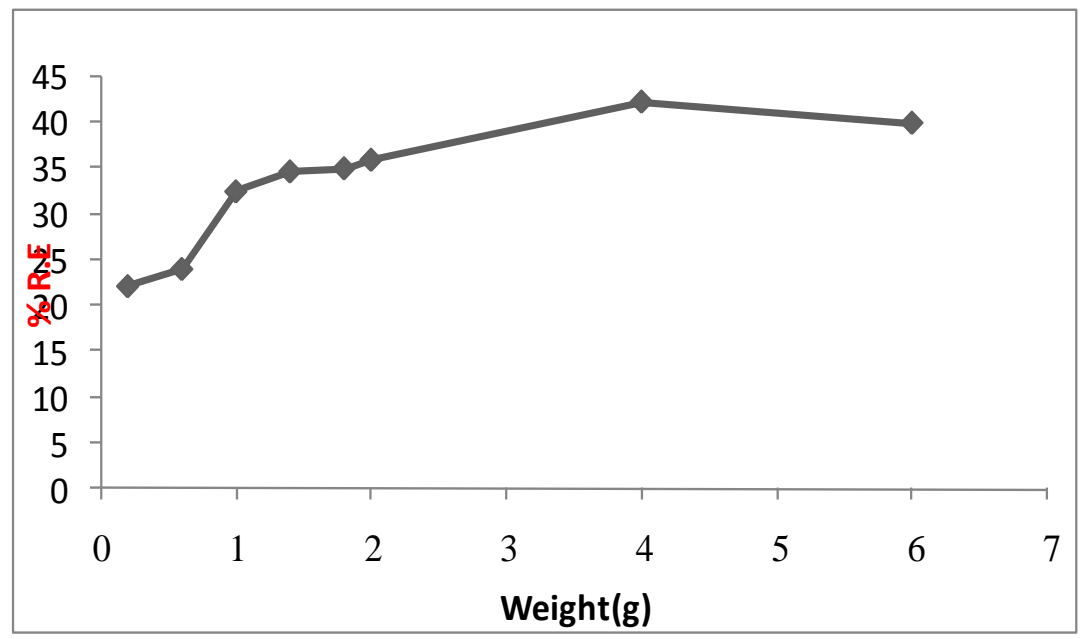

Figure.2 Effect of adsorbent mass to remove direct red 81 by filter cake $\left(\mathrm{C}_{0}=50 \mathrm{mg} / \mathrm{L}, \mathrm{pH}=2, \mathrm{w}=0.2-6 \mathrm{~g}\right.$, particle size $=$ $0.063 \mathrm{~mm}$, contact time $=60 \mathrm{~min}$ )

\subsubsection{Effect of $\mathrm{pH}$ on the adsorption of dye on the filter cake.}

The effect of $\mathrm{pH}$ on the removal efficiency of the direct red 81 by filter cake was investigated in the $\mathrm{pH}$ range 2-10.The results are depicted in Figure. 3 that reveals a gradual decrease of dye removal 
by increasing the $\mathrm{pH}$ and the highest $\mathrm{R} . \mathrm{E} \%$ occur at $\mathrm{pH}=2$ with a removal efficiency of $76.1 \%$. Clearly at lower $\mathrm{pH}$ the surface of filter cake is covered with the $\mathrm{H}^{+}$and consequently there was attractive force with the negatively charged dye .As the $\mathrm{pH}$ increases the positive sites decrease with an concomitant increase in the negatively charged sites $\left(\mathrm{OH}^{-}\right.$groups) that lead gradually to repulsive forces with anionic direct red 81 .

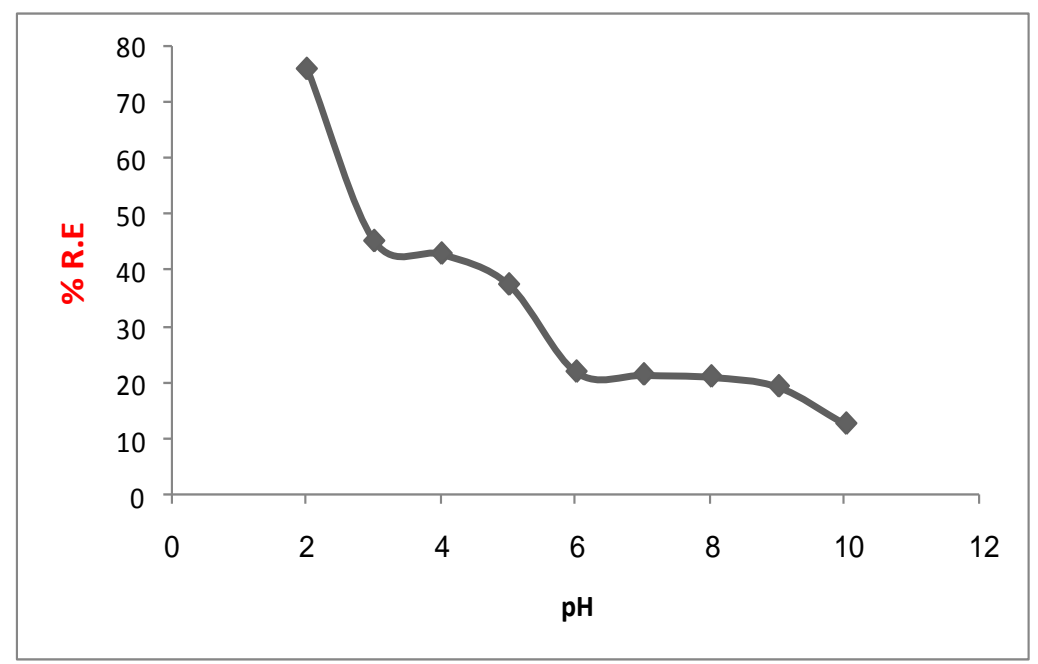

Figure.3 Effect of $\mathrm{pH}$ on the removal direct red 81 by filter cake $\left(\mathrm{C}_{0}=50 \mathrm{mg} / \mathrm{L}, \mathrm{pH}=2-10, \mathrm{w}=4 \mathrm{~g}\right.$, particle size $=0.063 \mathrm{~mm}$, contact time $=60 \mathrm{~min}$ )

\subsubsection{Effect of contact time on the adsorption of the dye.}

One of the most important parameters that significantly describe adsorbent characteristics is contact time. Therefore the effect of contact time on the adsorption of direct red 81 was investigated. Figure. 4 showed the adsorption of direct red 81 by filter cake as a function of contact time. The optimum time for adsorption was $60 \mathrm{~min}$. Generally, the percentage of dye adsorption increases with increase in contact time up to a certain extent. After this point, due to the lack of available adsorption sites, the percentage removal of dye is not affected ${ }^{[9]}$. At this point, the amount of dye desorbing from the adsorbent is in a state of dynamic equilibrium with the amount of the dye being adsorbed onto the 
adsorbent. It is apparent from the figure that till a time of $20 \mathrm{~min}$ the percentage removal of the dye increases rapidly and reaches $27 \%$. Afterwards there is a slow increase till contact time of $60 \mathrm{~min}$, then a slight decrease occurs. To rationalize the results, one can assume that the faster rate of adsorption in the initial time of adsorption is attributed to the availability of sites for dye adsorption and the process is accompanied with a high adsorption driving force. The decrease in $\%$ removal at times $>60 \mathrm{~min}$ is probably due to repulsive forces between the dye molecules adsorbed on the filter cake and those in the bulk phase that prohibit the dye molecules from being adsorbed on the remaining unoccupied sites on filter cake ${ }^{[9]}$.

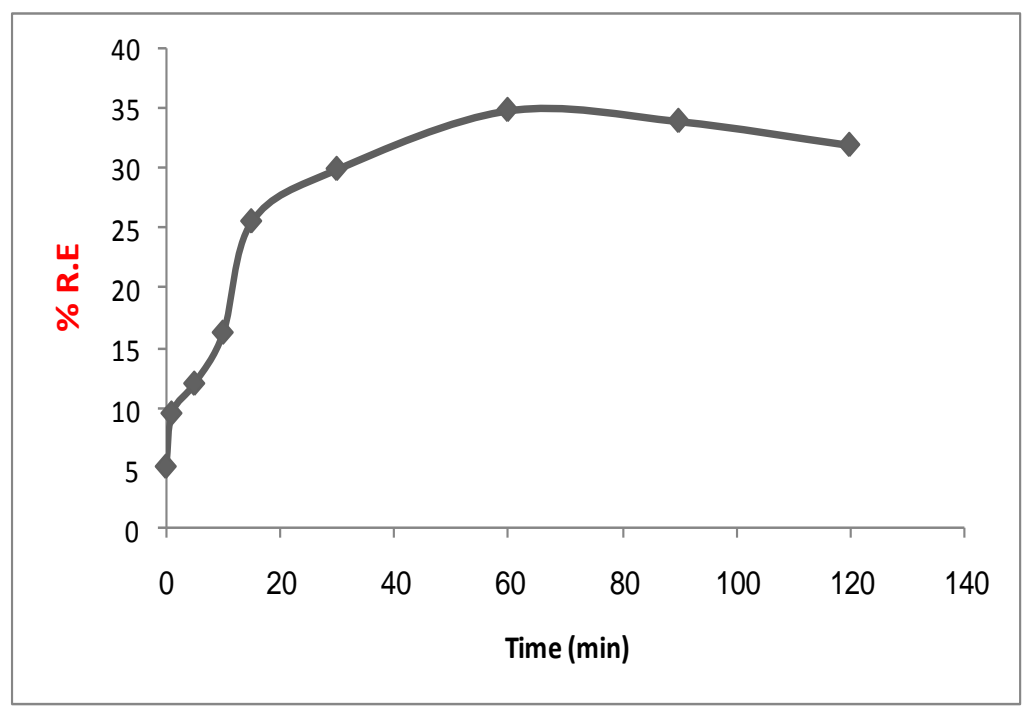

Figure.4 Effect of contact time on the removal direct red 81 $\left(\mathrm{C}_{0}=50 \mathrm{mg} / \mathrm{L}, \mathrm{pH}=2, \mathrm{w}=4 \mathrm{~g}\right.$, particle size $=0.063 \mathrm{~mm}$, contact time $=1-120 \mathrm{~min})$.

\subsubsection{Effect of particle size of adsorbent on the adsorption of dye}

The variation of adsorbent particle size was investigated from 0.063 to $0.5 \mathrm{~mm}$ and the results are incorporated in Figure. 5 .The figure showed a decreasing trend of adsorption as the particle size increases. This can be ascribed to the decrease in surface area of the adsorbent as its particle size increases. Particle size of $0.063 \mathrm{~mm}$ was chosen to be the best one to perform all the batch experiments. 
It is to be noted that other factors rather than surface may also be responsible for the above mentioned such as blockage of some sections on the particle surface leading to such adsorption decrease ${ }^{[10]}$.

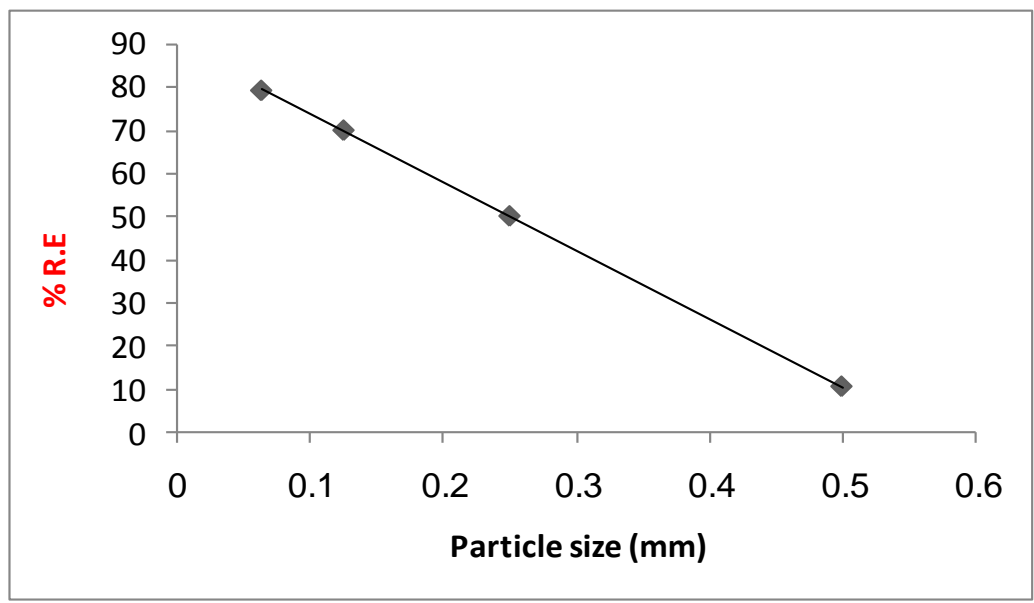

Figure. 5 Effect of particle size of adsorbent on the direct red 81 removal $\left(\mathrm{C}_{0}=50 \mathrm{mg} / \mathrm{L}, \mathrm{pH}=2, \mathrm{w}=4 \mathrm{~g}\right.$, particle size $=0.063$ $0.5 \mathrm{~mm}$, contact time $=60 \mathrm{~min}$ )

\subsection{Adsorption isotherms}

The adsorption isotherms are important to optimize the design of an adsorption system to remove the dye. The parameters obtained from the different isotherms provide important information about the adsorption mechanisms and surface properties. The most widely accepted surface adsorption models are Langmuir, Freundlich, Dubinin and Tempkin models

\subsubsection{Langmuir isotherm model}

The mathematical formula of this model can be expressed as

$$
q_{e q}=\frac{q_{\max } b c_{e}}{1+b c_{e}}
$$

The linear form of Langmuir is

$$
\mathrm{C}_{\mathrm{e}} / \mathbf{q}_{\mathrm{e}}=\left(1 / \mathbf{q}_{\operatorname{maxb}}\right)+\left(\mathrm{C}_{\mathrm{e}} / \mathbf{q}_{\mathrm{m}}\right)
$$


where $\mathrm{C}_{\mathrm{e}}$ is concentration of adsorbate at equilibrium and $\mathrm{q}_{\mathrm{m}}$ is the maximum adsorption capacity of the dye per unit mass of the adsorbent. The value $b$ of Langmuir constant $(\mathrm{L} / \mathrm{mg})$ represents $a$ ratio of adsorption rate constant to desorption rate constant. Plotting $\left(\mathrm{C}_{\mathrm{e}} / \mathrm{q}_{\mathrm{e}}\right)$ vs $\mathrm{C}_{\mathrm{e}}$ gives a straight line of very low correlation coefficient indicating that the Langmuir isotherm model cannot be applied to the adsorption of direct red 81 on filter cake (Figure.6).

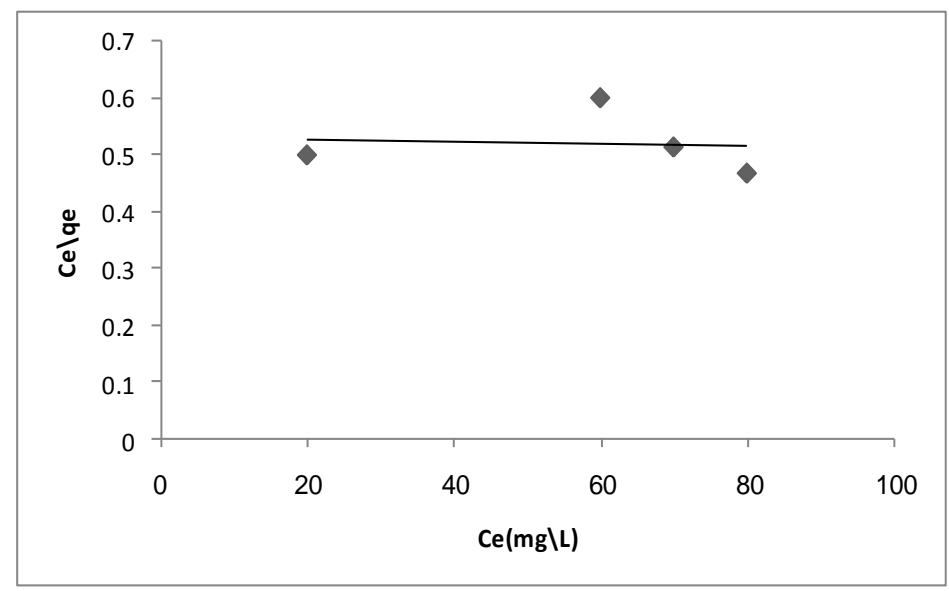

Figure. 6 Langmuir isotherm for direct $\operatorname{red} 81\left(C_{0}=10-80 \mathrm{mg} / \mathrm{L}\right.$, $\mathrm{pH}=2, \mathrm{w}=4 \mathrm{~g}$, particle size $=0.063 \mathrm{~mm}$, contact time $=60 \mathrm{~min})$.

\subsubsection{Freundlich isotherm model}

The general form of the Freundlich isotherm equation is written as follows :

$$
q_{e}=K_{f} C_{e}^{1 / n}
$$

The linear form of this model is given in equation

$$
\log q_{e}=1 / n \log C_{e}+\log K_{f}
$$

where, $K_{f}$ and $n$ are the adsorption capacity and the intensity of adsorption, respectively. If $1 / \mathrm{n}$ is lower than 1.0 , then the adsorbate is favorably adsorbed on the adsorbent $(0<1 / \mathrm{n}<1)$. The type of isotherm can be also irreversible, $1 / n=0$ or unfavorable, $1 / n>1$. The values of $K_{f}$ and $1 / n$ are 2.7 and 0.899 , respectively. The value of 
$1 / \mathrm{n}$ is less than unity which indicates that the sorption of direct red 81 was found to follow the Freundlich equation.

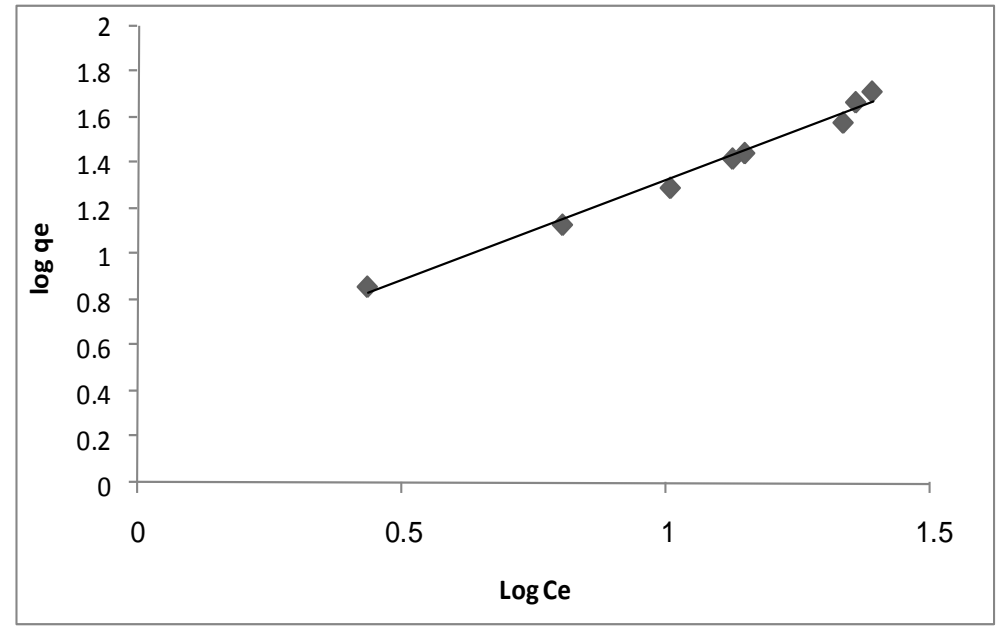

Figure. 7 Freundlich isotherm plot $\left(\mathrm{C}_{0}=10-80 \mathrm{mg} / \mathrm{L}, \mathrm{pH}=2\right.$ $, \mathrm{w}=4 \mathrm{~g}$, particle size $=0.063 \mathrm{~mm}$, contact time $=60 \mathrm{~min})$

\subsubsection{Tempkin isotherm model}

This isotherm assumes that the heat of adsorption of the molecules on the surface decreases linearly and not logarithmically. It postulates also the uniform distribution of the binding energies in an adsorption process. It covers also the adsorbate. adsorbent interaction [10]. Equation (7) represents the non-linear form of Tempkin isotherm:

$$
\mathbf{q}_{\mathrm{e}}=\mathbf{R T} / \mathbf{b} \ln \left(\mathrm{Ac}_{\mathrm{e}}\right)
$$

The linear form of this equation is

$$
q_{e}=B_{T} \operatorname{Ln~} A_{T}+B_{T} \operatorname{LnCe}
$$

where $\mathrm{B}_{\mathrm{T}}=\mathrm{RT} / \mathrm{b}_{\mathrm{T}}$ and $\mathrm{T}$ and $\mathrm{R}$ are absolute temperature and $\mathrm{R}=8.314 \mathrm{Jmol}^{-1} \mathrm{~K}^{-1}$. The constant $\mathrm{B}_{\mathrm{T}}$ and $\mathrm{b}_{\mathrm{T}}$ are related to the heat of adsorption. $\mathrm{A}_{\mathrm{T}}$ represents the equilibrium binding constant and corresponds to the maximum binding energy $(\mathrm{L} / \mathrm{g})$. The parameters $\mathrm{A}_{\mathrm{T}}, \mathrm{B}_{\mathrm{T}}$ and $\mathrm{b}_{\mathrm{T}}$ are compiled in Table(1) and the plot $\mathrm{q}_{\mathrm{e}}$ vs $\ln \mathrm{c}_{\mathrm{e}}$ is depicted in Figure 8. 


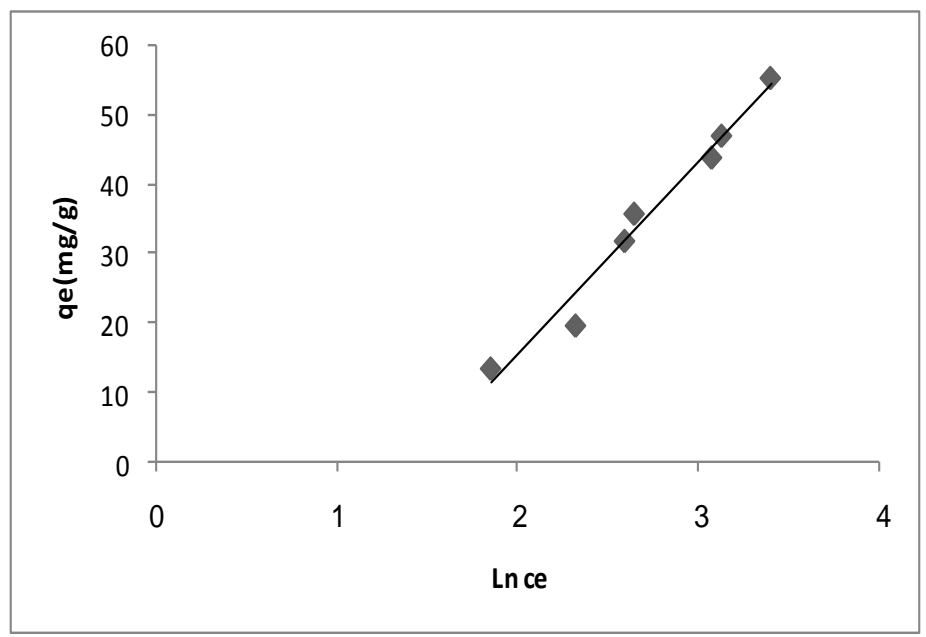

Figure.8 Tempkin isotherm plot of direct red 81 on filter cake $\left(\mathrm{C}_{0}=10-80 \mathrm{mg} / \mathrm{L}, \mathrm{pH}=2, \mathrm{w}=4 \mathrm{~g}\right.$, particle size $=0.063 \mathrm{~mm}$, contact time $=60 \mathrm{~min}$ )

\subsubsection{Dubinin- Radushkevich (D-R) isotherm model}

According to this model it is postulated that there is no homogenous surface to exist. The linear form of this isotherm is given by equation 9 and the corresponding plot is shown in Fig 9.

$$
\operatorname{Lnq}_{\mathrm{e}}=\ln \mathrm{q}_{\mathrm{m}}+\boldsymbol{\beta} \boldsymbol{C}^{2}
$$

where $\mathrm{q}_{\mathrm{e}}$ and $\mathrm{q}_{\mathrm{m}}$ were defined in Langmuir equation and in $\mathrm{D}-\mathrm{R}$ equation refers to the degree of sorbate adsorption on the adsorbent surface. $\beta$ is the

$\mathrm{D}-\mathrm{R}$ isotherm constant that is associated with the mean free energy of adsorption. $C$ is known as the Polanyi potential and is expressed by the following equation:

$$
G=\operatorname{RT} \operatorname{Ln}\left(1+1 / C_{e}\right)
$$

This model, however, is usually applied to determine the mean free energy of adsorption (E). According to eq.11 an 
adsorption process is called physical if the value of $E_{D}$ is less than $8 \mathrm{KJmol}^{-1}$. Values of E between 8 and $16 \mathrm{KJmol}^{-1}$ refer to chemical adsorption process .

$$
E=\frac{1}{\sqrt{2 B}}
$$

In this study the correlation coefficient $\left(\mathrm{R}^{2}=0.9816\right)$ indicates agood fit of this model to the experimental equilibrium data. The value of $E$ calculated from the above equation is 3.8 $\mathrm{kJmol}^{-1}$ which reflects the physisorption of direct red 81onto the filter cake. In addition ,the value of $\beta\left(0.033 \mathrm{~mol}^{2}(\mathrm{~kJ})^{-2}\right)$, is less than unity implying that several cycles are required to reduce the dye concentration to an appropriate level by filter cake.

Table 1 collects the relevant parameters of Freundlich, Tempkin and Dubinin isotherms . As a final remark on the isotherm study it is to be noted that the Freundlich isotherm model gives the best correlation coefficient among the four studied isotherm model. So, this model represents the best one for studying the relation between equilibrium concentration of the dye in the solid and liquid phases. The result indicates the surface heterogeneity nature of the adsorbent. This is more substantiated by the high correlation coefficient of D-R model that is also be applied to heterogeneous systems. This behavior was also observed in some systems for dye removal $^{[11]}$. 


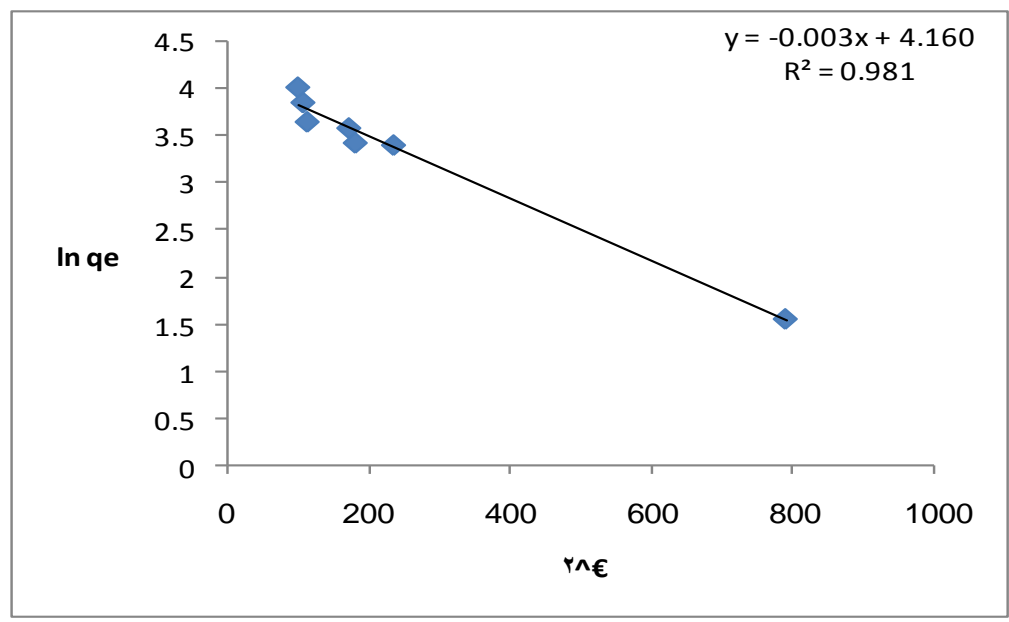

Figure.9 Dubinin- Radush kevich is otherm plot for direct red 81 adsorption on filter cake. $\left(\mathrm{C}_{0}=10-80 \mathrm{mg} / \mathrm{L}, \mathrm{pH}=2, w=4 \mathrm{~g}\right.$, particle size $=0.063 \mathrm{~mm}$, contact time $=60 \mathrm{~min}$ ).

Table (1) Frendlich, Tempkin and Dubinin isotherm constants of direct red 81 adsorption by filter cake.

\begin{tabular}{|c|c|c|}
\hline Model & parameters & Values \\
\hline Langmuir & $\mathbf{q}_{\mathbf{e x p}}$ & \\
Isotherm & $\mathbf{b}(\mathbf{L} / \mathbf{m g})$ & not applicable \\
& $\mathbf{q}_{\mathbf{m}}(\mathbf{m g} / \mathbf{g})$ & \\
\hline Freundlich & $\mathbf{R}^{\mathbf{2}}$ & \\
Isotherm & $\mathbf{K}_{\mathbf{f}}(\mathbf{L} / \mathbf{m g})$ & $\mathbf{2 . 8 1}$ \\
& $\mathbf{1} / \mathbf{n}$ & $\mathbf{0 . 8 7 8}$ \\
& $\mathbf{R}^{2}$ & $\mathbf{0 . 9 8 6}$ \\
\hline Temkin & $\mathbf{B}_{\mathbf{T}}$ & $\mathbf{2 7 . 7}$ \\
Isotherm & $\mathbf{A}_{\mathbf{T}}(\mathbf{L} / \mathbf{g})$ & 4.2 \\
& $\mathbf{b}_{\mathbf{T}}\left(\mathbf{J} / \mathbf{m o l}^{\mathbf{2}}\right)$ & $\mathbf{8 9 . 2}$ \\
& $\mathbf{R}^{\mathbf{2}}$ & $\mathbf{0 . 9 7 3 5}$ \\
\hline Dubinin- & $\mathbf{K}_{\mathbf{D}-\mathbf{R}}$ & $\mathbf{0 . 0 3 3}$ \\
Radushkevich & $\mathbf{E}(\mathbf{k J} / \mathbf{m o l})$ & $\mathbf{3 . 8 9 2 5}$ \\
& $\mathbf{q}_{\mathbf{m}}$ & 64.1 \\
& $\mathbf{R}^{\mathbf{2}}$ & $\mathbf{0 . 9 8}$ \\
\hline
\end{tabular}




\subsection{Sorption kinetics studies}

In order to evaluate the kinetic study of the dye adsorption to the filter cake adsorbent four kinetic models were investigated. These are pseudo -first order, pseudo-second -order, Elovich and intra-particle diffusion models.

\subsubsection{Pseudo- first order kinetic model}

This model is given by equation (12) as a linear form.

$$
\log \left(q_{e}-q_{t}\right)=\log q_{e}-\frac{k_{1}}{2.303} t
$$

where $\mathrm{q}_{\mathrm{t}}$ is the adsorption capacity $\left(\mathrm{mgg}^{-1}\right)$ at a time $\mathrm{t}$ and $\mathrm{k}_{1}$ is the rate constant of the first order adsorption $\left(\mathrm{min}^{-1}\right)$.

Fig. 10 show the drawing of $\log \mathrm{q}_{\mathrm{e}}-\mathrm{q}_{\mathrm{t}}$ against $\mathrm{t}$

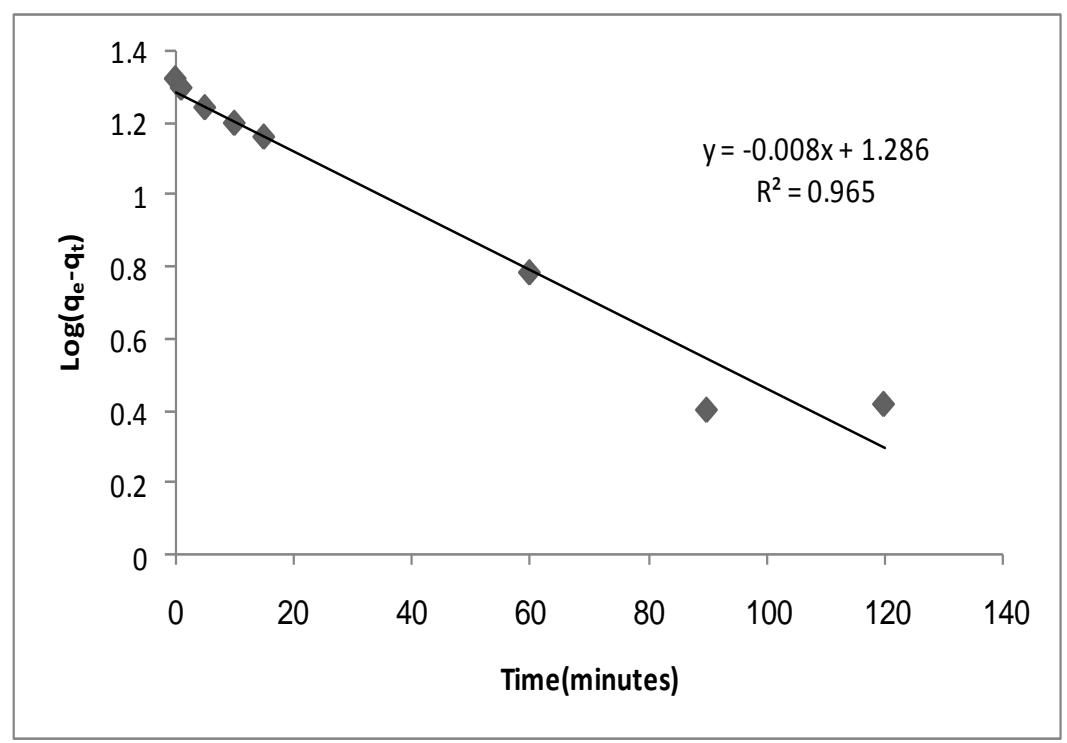

Figure.10 pseudo-first order model of direct red 81 sorption on Filter cake $\left(\mathrm{C}_{0}=50 \mathrm{mg} / \mathrm{L}, \mathrm{pH}=\mathbf{2}, \mathrm{w}=\mathbf{4 g}\right.$, particle size $=$ $0.063 \mathrm{~mm}$, contact time $=1-120 \mathrm{~min}$ ) 


\subsubsection{Pseudo - second order kinetics}

The linear form of this model can be represented by the following equation(eq.13)

$$
\frac{t}{q}=\frac{1}{k_{2} q_{e}^{2}}+\frac{1}{q_{e}} \mathbf{t}
$$

where $\mathrm{h}=\mathrm{k}_{2} \mathrm{q}_{\text {e }}^{2}$ can be regarded as the initial sorption rates as $\mathrm{t}=0$. The plot of $\mathrm{t} / \mathrm{q}_{\mathrm{t}} \mathrm{vs}$. $\mathrm{t}$ gives a linear relationship allowing calculation of $\mathrm{q}_{\mathrm{e}}$ and $\mathrm{k}_{2}$ (Figure. 11). The correlation coefficient $\mathrm{R}^{2}$ is (0.96) for the pseudo- first order kinetics .However is $(0.99)$ for the pseudo- second order kinetics indicating pseudo- second order kinetics models are suitable for direct red 81 adsorption on filter cake. The parameters of this model are tabled in Table (2).

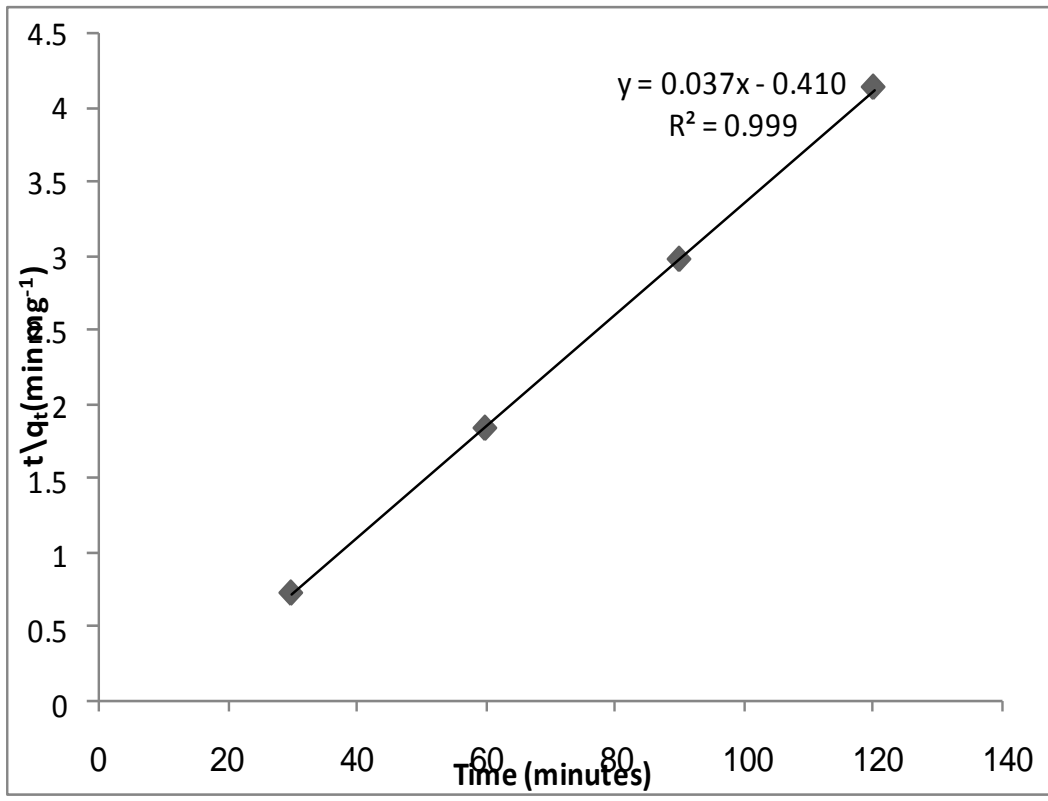

Figure.11 Pseudo second order kinetic of direct red 81 on filter cake $\left(\mathrm{C}_{0}=50 \mathrm{mg} / \mathrm{L}, \mathrm{pH}=2, \mathrm{w}=4 \mathrm{~g}\right.$, particle size $=$ $0.063 \mathrm{~mm}$,contact time $=1-120 \mathrm{~min}$ ). 
Table (2) Kinetic parameters obtained from pseudo-secondorder for direct red 81 by filter cake.

\begin{tabular}{|c|c|c|}
\hline Model & Parameters & Values of parameters \\
\hline $\begin{array}{c}\text { Pseudo second } \\
\text { order }\end{array}$ & $\mathbf{K}_{2}\left(\mathrm{~min}^{\mathbf{1}}\right)$ & $\mathbf{0 . 0 9 2 0}$ \\
& $\mathrm{q}_{\mathrm{e}}(\mathrm{mg} / \mathrm{g})$ & $\mathbf{2 6 . 4 5 5}$ \\
& $\mathbf{R}^{2}$ & $\mathbf{0 . 9 9 9 9}$ \\
\hline
\end{tabular}

\subsubsection{Elovich isotherm model}

Elovich equation is a rate equation based on the adsorption capacity. Its linear form is expressed in the following equation (equation.14):

$$
q_{t}=1 / \beta \operatorname{Ln}(\alpha \beta)+1 / \beta \operatorname{Ln}(t)
$$

where $\alpha\left(\mathrm{mg} / \mathrm{gmin}^{-1}\right)$ is the initial adsorption rate and $\beta(\mathrm{g} / \mathrm{mg})$ is the adsorption constant related to the surface coverage and activation energy. The plot of $\mathrm{q}_{\mathrm{t}}$ against $\mathrm{Ln}$ is depicated in Fig.12.

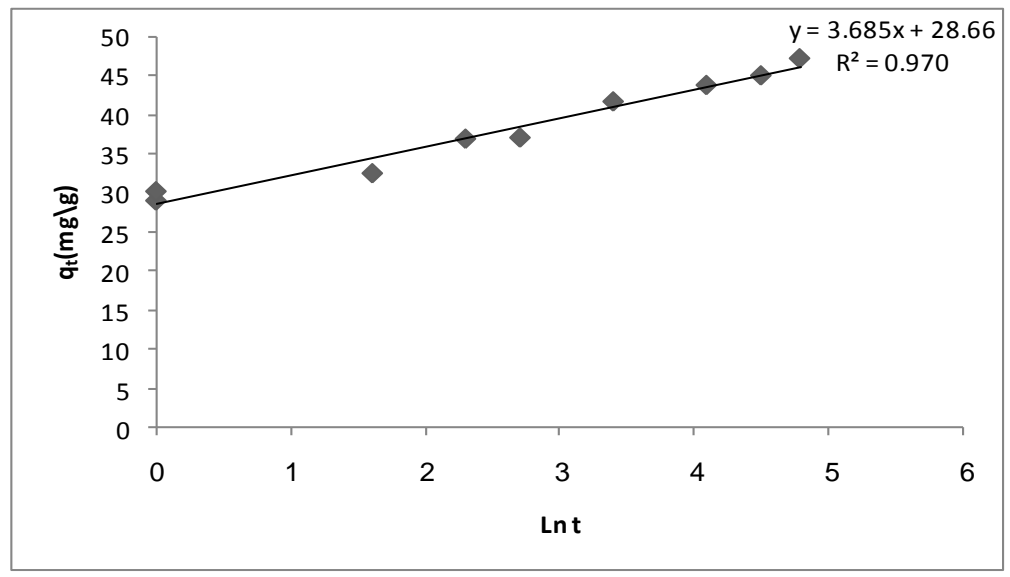

Figure.12 Elovich Kinetic model of direct red (81) on Filter cake $\left(\mathrm{C}_{0}=50 \mathrm{mg} / \mathrm{L}, \mathrm{pH}=2, \mathrm{w}=\mathbf{4 g}\right.$, particle size $=0.063 \mathrm{~mm}$, contact time $=1-120 \mathrm{~min}$ ) 


\subsubsection{Intra-particle diffusion model}

The intra-particle diffusion is another kinetic model that applied in this study to the adsorption of direct red 81 by filter cake. This model is commonly given by the following equation:

$$
\mathbf{q}_{t}=\mathbf{K}_{\text {dif }} \mathbf{t}^{1 / 2}+\mathbf{C}
$$

where $\mathrm{C}\left(\mathrm{mgg}^{-1)}\right.$ is the intercept and $\mathrm{K}_{\mathrm{dif}}$ is the intra-particle diffusion rate constant $\left(\mathrm{mgg}^{-1} \cdot \mathrm{min}^{-1 / 2}\right)$.

In this study the value of $\mathrm{q}_{\mathrm{t}}$ were found to be linearly correlated with that of $\mathrm{t}^{1 / 2}$ (Figure.13). However, the linearity of the plot indicates that the intra-particle diffusion is important in the dye adsorption. But as the plot did not pass through the origin, intraparticle diffusion is not the only rate-limiting step ${ }^{[11]}$.

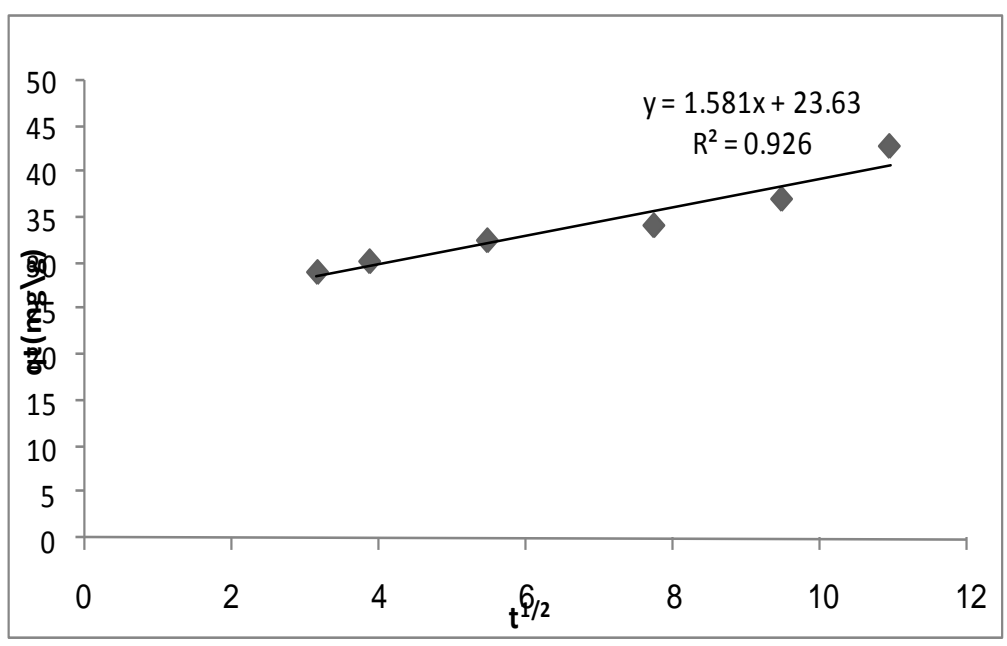

Figure.13 Intraparticle diffusion model for adsorption direct red 81 on filter cake. $\left(\mathrm{C}_{0}=50 \mathrm{mg} / \mathrm{L}, \mathrm{pH}=2, \mathrm{w}=4 \mathrm{~g}\right.$, particle size $=0.063 \mathrm{~mm}$, contact time $=1-120 \mathrm{~min}$ )

\section{Comments and remarks .}

Some reports suggest that pseudo-first order points to a physisorption process $^{[12]}$ while the pseudo-second order process refers to chemisorption one ${ }^{[13]}$. The obtained results in this investigation indicate that the pseudo-second order possesses a 
higher correlation coefficient than the pseudo-first order in accord with chemisorption process. Furthermore, the high correlation coefficient of Elovich model $(\mathrm{R}=0.9708)$ is also in agreement with chemisorption process. However, taking into account the low $\mathrm{E}_{\mathrm{D}}$ and $b_{\mathrm{T}}$ values which may be associated with a physisorption process, one can propose, based on the aforementioned arguments, that the adsorption of direct red 81 is governed by a physisorption process with some chemisorption contribution.

\section{Conclusion}

We could successfully remove direct red 81 with the beet sugar waste filter cake. The optimum conditions of such removal were adjusted including dye concentration, contact time, adsorbent particle size and weight. The results from this work constitute with the previous work on beet pulp and beet leaves (the results of which will be published latter) a continuous set of contributions towards using the industrial beet sugar wastes in dye removal.

\section{References}

[1] Wawwrzkiewicz M., Polska-Adach E.,Hubicki Z.," Application of titania based adsorbent for removal of acid , adsorption reactive and direct dyes from textile effluents", Physicochemical Problems of Mineral Processing.,25:621630(2019).

[2] Tagac A.A., Yurdakos M.K., "Adsorption of Remazol Blue $(\mathrm{Rb})$ onto the chitosan/SEP biocompsite from aqueous solution ", J.Sci. Eng., 20:286-298(2018).

[3] Ngulube T., Gumbo J.R., Masindi V., Maity A., "Calcined magnesite as an adsorbent for cationic and anionic dyes: characterization, adsorption parameters, isotherms and kinetic study, Heliyon".4:e00838(2018).

[4] Marti M.E., Zeidan H.,"Evaluation of sugar beet processing lime cake for the removal of synthetic dyes from aqueous solutions, AICHE Annual Meeting, Minneapolis ,MN"(2017). 
[5] Kawanga K.D., Gateba E., Mauti G.O., Mauti E.M.,"Kinetics, sorption isotherms, pseudo-pseudo-second order model studies of $\mathrm{Cu}(\mathrm{II})$ and $\mathrm{pb}(\mathrm{II})$ using defatted Maringa oleifra seed powder ", The Journal of Phytopharmacology ,5:7178(2016).

[6] Salman T., Temel F.A., Turan N.G., Ardali Y.,"Adsorption of lead (II) ions onto diatomite from aqueous solution: mechanism, isotherm and kinetic studies", Global Nest J., 18: 4-10(2016).

[7] Amin M.T., Alazba A.A., Shafia M.,"Adsorptive removal of reactive black from wastewater using bentonite clay: isotherms, Kinetics and thermodynamics, Journal sustainability", 7:1530215318(2015).

[8] Mahmoodi N., M., AbdiAli J., Bastani D., "Direct dyes removal using modified magnetic ferrite nanoparticle ", Environ. Sci. Eng.12:96(2014).

[9] Said A.A., Aly A.A.M., Abd EL-Wahab, M.M., Soliman S.A., Abd EL-Hafez A.A., Helmy V.,Goda M.N.,"Application of modified bagasse as abiosorbent for reactive dyes removal from industrial wastewater", water Res.protection,10-17(2013).

[10] Rodriguez A., Ovejero G., Mestanza M., Garcia J.,"Dyes adsorption on low cost adsorbents: inorganic material", Journal of Desalination and water Treatment, 45:191-205(2012).

[11] Santhi M, Smith T., "Removal of malachite green from aqueous solution by activated carbon prepared from the Annona squmosa seed by adsorption,Drbital", The Electronic J.Chem,2:101-11(2010).

[12] Santhi T., Munonmani,"Removal of methylene blue from aqueous solution by biosorption onto Ricinus communis epicarp activated carbon", Chem.Eng.Res,Bull.13:1-5(2009).

[13] Yavuz O., Aylin A.H.,"Removal of direct dyes from aqueous solution using various adsorbents", pol.J.Environ.Studies ", Pol.J.Environ.Studies, 15:155-161(2006). 


\section{الالغم العرببي}

استخدام الطينة الصفراء الناتجة هن هذلفات بنجر السكر في ازالة صبغة الديريكت ريد 81 هن المحاليل المائية

عارف احمد هممدعلى ، هممد هممود هممد عبدالوهاب 1،، صدقي حسن ،ابراهيم عبد الغنى ، عبير عبد الحى على فراج2

$$
\text { قسمالكيمياء - كالية العلوم- جامعة اسيوط - مصر. }
$$

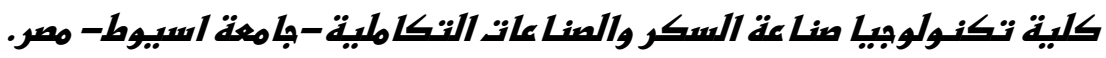

قسمالنبات والميكروبيولوهيي - كلية العلوم - جامعة الوادي البديد - مصر.

شركة الدلنا للسكر والصنا عات النكاملية - كهر الشيف - مصر.

يعد تلوث المياه من اهم مشاكل التلوث لما للماء من دور كبير في

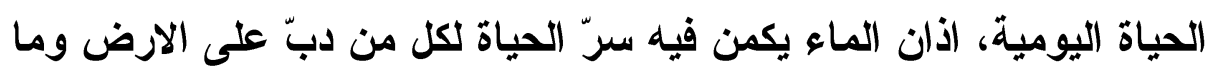
يخرج من نبات فضلاً عن ان الماء يعد عنصرا اساسياً في الصناعة، اذ تحتاج الصناعات المختلفة كميات هائلة من المياه تتفاوت من حيث نوعيتها ودرجة نقاوتها طبقا لمواصفات معينة تطلبها كل صناعة وتعد الاصباغ من بين المواد من من مئ العضوية المتعددة الملوثة للمصادر المائية ويعود السبب في ذلك الى اهميتها الكبيرة واستخدامها الواسع في الصناعات المتنوعة فهي تستخدم في الصناعات النسيجية وفي الطباعة وفي الوان التصوير الفوتوغرافي وكمضافات في الصناعات النفطية فضلا عن استخدامها في مجالات واسعة اخري لا حصر لها. ومن اهم التقنيات التي استخدمت في معالجة مشكلة تلوث المياه الامتزاز. ويعد الامتزاز من اهم التقتيات لكفاعته العالية بالإضافة الي تكلقته الاقتصادية الاقل. الهُف من تلكك الورقة البحثية هو دراسة مدي كفاعة الطينة الصفراء في ازاله صيغة الايركت ريد 81 من محلولها المائي مع دراسة تأثثر مجموعة 
من العوامل علي امتزاز الصبغة مثل الدالة الحامضية للمحلول ، زمن الرج،

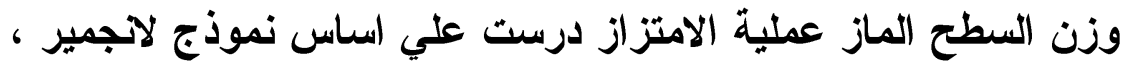
فرينلش، تمكين، دوبين وقد وجد ان نموذج فرينليش ينطبق على عملية امتزاز الصبغة بلرجة اكبر من باقى النماذج • ايضا تم دراسة نموذج الرتبة الاولى الكاذبة ،الرتبة الثانية الكاذبة،

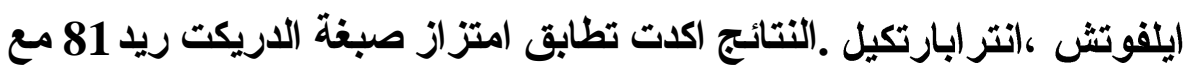

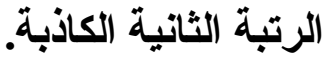

\section{Nom}

